\title{
LOAD AGGRESSIVENESS ON DIFFERENT PAVEMENT STRUCTURES DUE TO THE WEIGHT INCREASE OF HEAVY VEHICLES FROM 40 TONNES TO 44 TONNES
}

\author{
ADRIANA MARTÍNEZ*, MAGÍN CAMPOS \\ School of Civil Engineering, Polytechnic University of Catalonia, \\ Barcelona, Spain
}

Received 9 December 2018; accepted 1 April 2019

\begin{abstract}
The load capacity of goods vehicles is a critical variable in calculating transport costs. In Europe, the Council Directive 96/53/EC establishes the maximum weight and dimensions of goods vehicles in international traffic but also allows that any Member State authorises the movement of vehicles that fail to comply with these weights and dimensions within its territory. For this reason, some countries have used this power to introduce internal regulations regarding the maximum transport capacity. A case of particular interest discussed in this article is the vehicle with five axles (two tractor axles and 3 -axle semitrailer), which is only allowed a maximum weight of $40 \mathrm{t}$ by the Directive above. While some countries allow a maximum weight of $44 \mathrm{t}$ when circulating within their territories, the limitation in Spain has been established by the Council Directive 96/53/EC of 25 July 199640 t, although this restriction is often discussed by the different agents related to the transport of goods by road. Therefore, this paper analyses the effect of T2S3 vehicles loaded with $42 \mathrm{t}$ and $44 \mathrm{t}$ on sections of flexible and semi-rigid pavements of the Spanish road
\end{abstract}

\footnotetext{
* Corresponding author. E-mail: adriana.martinez@upc.edu

Adriana MARTÍNEZ (ORCID ID 0000-0002-3709-0463)

Magín CAMPOS (ORCID ID 0000-0002-2880-361X) 
network, to provide information about the impacts of the modification of the regulations on capacity.

Keywords: flexible pavements, heavy vehicles, maximum permitted weight, pavement design, semi-rigid pavements.

\section{Introduction}

The load capacity of goods vehicles is a critical variable in calculating transport costs. In Europe, there is a Council Directive 96/53/EC of 25 July 1996 laying down for certain road vehicles circulating within the Community the maximum authorised dimensions in national and international traffic and the maximum authorised weights in international traffic. This Directive establishes the maximum weight and dimensions of goods vehicles in international traffic but also allows that any Member State authorises the movement of vehicles that fail to comply with these weights and dimensions within its territory, and for this reason, some countries have used this power to introduce internal regulations regarding the maximum transport capacity.

A case of particular interest, discussed in this article, is the vehicle with five axles (two tractor axles and 3-axle semitrailer - commonly called T2S3), which is only allowed a maximum weight of $40 \mathrm{t}$ by the Directive above. Countries such as France, Italy, Belgium and Luxembourg, allow a maximum weight of $44 \mathrm{t}$ when circulating within their territories, but others, such as Denmark, Czech Republic and Greece, allow no more than $42 \mathrm{t}$ (International Transport Forum, 2016). In Spain, the limitation has been established by the European Directive 40 t (Dirección General de Tráfico,... 2013), although this restriction is often discussed by the different agents related to the transport of goods by road (Alianza por la competitividad..., 2013).

The internal transport of goods among member states of the EU represents approximately $75 \%$ of tonne-km, (European Commission Directorate-General..., 2014), and in Spain, according to the Observatorio del Transporte de Mercancías por Carretera (Gobierno de España, 2016), it accounted for almost $79 \%$ in 2014 , and has exceeded $83 \%$ in previous years.

The advantages associated with a change in the capacity of these vehicles are reducing fuel consumption and emission of greenhouse gases. Although fuel consumption increases with vehicle weight, specific fuel consumption is reduced when the variable analysed is the amount of litters per ton-km of goods transported, since the amount of travel required is reduced, as has been demonstrated by Hedberg (2008). It is expected therefore to reduce $\mathrm{CO}_{2}$ emissions by reducing 
fuel consumption, a fact commented on studies such as Leonardi \& Pavement Baumgartner (2004).

The counterpart of these benefits is presented when the effect of this overload on the road infrastructure is evaluated. By increasing the axle load, the stress transmitted to the pavement also increases and therefore, it is necessary to determine the potential aggressiveness of maximum mass change. This topic has been the subject of studies focused on maximum vehicle mass $60 \mathrm{t}$, also known as mega truck, or officially as a vehicle for euro-modular configuration, (Díaz, Echaveguren, \& Vargas-Tejeda, 2012; Leduc, 2009; Steer, Dionori, Casullo, Vollath, Frisoni, Carippo, \& Ranghetti, 2013).

The effect caused by vehicles on the pavement depends on the configuration of vehicle load and also on other variables such as the volume of the moving vehicle, the pavement structure and climatic conditions. The load repetitions combined with all these features will damage the pavement, causing typical distresses as fatigue cracking, rutting, and lack of roughness. In order to assess the impact of repetition of different axle loads, it is frequently used the concept of Equivalent Axle Load (ESALs) as well as the law of the fourth power, derived from the American Association of State Highway and Transportation Officials (AASHO) Road Test in the USA (Highway Research Board, 1961).

For the previous reasons, this paper analyses the effect of T2S3 vehicles loaded with $42 \mathrm{t}$ and $44 \mathrm{t}$ on sections of flexible and semi-rigid pavements of the Spanish road network. The objective is to provide information about the impacts and benefits of the modification of the regulations on capacity.

\section{Methodology}

The work methodology consisted of calculating the stress state of different pavement structures analysed when they are subjected to the axle loads of heavy vehicles type T2S3, considering different load configurations (15.5 t, $40 \mathrm{t}, 42 \mathrm{t}$ and $44 \mathrm{t}$ ).

The pavement structures analysed correspond to those defined as flexible and semi-rigid sections from the Spanish Guidelines Norma 6.1-IC "Secciones de firme", aprobada por la Orden FOM 3460/2003.

The elastic multilayer model developed by Burmister, Palmer, Barber, \& Middlebrooks (1944), was used for the calculation of the stressstrain state of these structures. This model assumes that the pavement is composed of horizontal layers of constant thickness that extend infinitely in the horizontal direction and supported on a homogeneous semi-infinite space (subgrade). Each layer and the subgrade are assumed 
to be linearly elastic, isotropic, continuous and homogeneous media, mechanically characterised by its Young modulus $(E)$ and Poisson ratio (v).

The determined parameters are the maximum horizontal strain in the lower fibre of the asphalt mixture layers, $\varepsilon h$, and maximum horizontal stress in the lower fibre of the cement-treated layer $\sigma h$. Both parameters have allowed assessing the aggressiveness of each of the heavy vehicles on the evaluated pavements.

To determine these parameters, Freeware BISAR 3.0 Stress Analysis in Bitumen Roads, developed by Shell, was used. The aggressiveness of each truck was calculated from the damage caused by the passage of their axles on a pavement, defined by Eqs (1) and (2) (Corté \& Goux, 1996; Kerzreho, Hornych, Chabot, Trichet, Gouy, Coirier, \& Deloffre, 2012).

$$
A_{i}=\left(\frac{\varepsilon_{i}}{\varepsilon_{0}}\right)^{\alpha} \text { - for flexible pavements }
$$

and

$$
A_{i}=\left(\frac{\sigma_{i}}{\sigma_{0}}\right)^{\alpha} \text { - for cement-treated layers in semi-rigid pavements, }
$$

where $A_{i}$ - the aggressiveness caused by one axle; $\varepsilon_{i}$ - the horizontal strain in the lower fibre of the layers of asphalt mixture due to the analysed axle; $\varepsilon_{0}$ - the horizontal strain in the lower fibre of the layers of asphalt mixture due to the reference axle; $\sigma_{i}$ - the horizontal stress in the lower fibre of the cement-treated layers due to the analysed axle; $\sigma_{0}$ - the horizontal stress in the lower fibre of the cement-treated layers due to the reference axle; $\alpha$ - the coefficient associated with the slope of the fatigue law of the materials.

The aggressiveness of a heavy vehicle, $A_{V P}$ is the sum of the aggressiveness of each of its axles Eq. (3):

$$
A_{V P}=\sum_{i=1}^{n} A_{i} .
$$

Coefficient $\alpha$ for the calculation of the aggressiveness of each load configuration was selected based on two hypotheses:

- hypothesis A - proposed by the French SETRA (Dauzats, Kobisch, Leroux, Odeon, Maribas, \& Delorme, 2003; Service d'Etudes Techniques..., 1994, 2009), of 5 for asphalt materials and 12 for cement-treated materials. These values were considered with the 


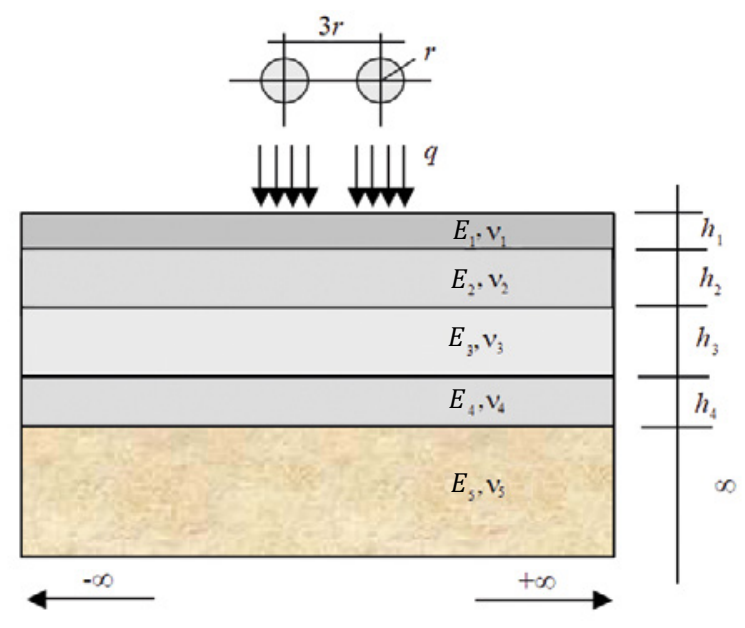

Note: $r$ - radius of a circle with the same contact area of the tyre print, $r=0.125 \mathrm{~m} ; P$ - standard axle load with dual wheels of $13 \mathrm{t}$ (used in Spain and France for the pavement design). The axle has four wheels, $P=3.25 \mathrm{t}$; $q$ - contact pressure, resulting from the division between $P$ and the contact area, $q=0.662 \mathrm{MPa} ; E_{i}$ and $v_{i}-$ Young Modulus and the Poisson ratio of each layer of pavement; $h_{i}$ - the thickness of each pavement layer.

Figure 1. Configuration of tyres for the standard axle over a multi-layered pavement characterised by Elastic modulus $\left(E_{i}\right)$, Poisson ratio $\left(U_{i}\right)$ and layer thickness $\left(h_{i}\right)$

aim of comparing the results with those usually taken as reference in Spain, hypothesis B because these are more conservative;

- hypothesis B - proposed by the Normas de Secciones de Firmes de la Comunidad Valenciana (Conselleria d'Infraestructures i Transport, 2009) and Kraemer, Pardillo, Rocci, Romana, Sánhez \& del Val (2004), of 4 and 8, respectively. These values are usually considered in the Spanish pavement design procedure.

A single axle with dual tyres loaded with $13 \mathrm{t}$ was considered as a standard. Following the methodology developed by SETRA (Service d'Etudes Techniques..., 2009), the data considered for the reference axle is shown in Figure 1.

\subsection{Pavement sections analysed}

Flexible and semi-rigid pavement sections from the catalogue of the Norma 6.1-IC were analysed, ranging from the highest traffic category (called T00) to the lowest one (T42), supported on two subgrade
Load Aggressiveness on Different

Pavement

Structures due to the Weight Increase of Heavy

Vehicles from 40 Tonnes to 44 Tonnes 
Table 1. Heavy traffic categories

\begin{tabular}{|c|c|c|c|c|c|c|c|c|}
\hline $\begin{array}{c}\text { Heavy } \\
\text { vehicle } \\
\text { traffic } \\
\text { categories }\end{array}$ & TоO & TO & T1 & T2 & T31 & T32 & T41 & T42 \\
\hline \multicolumn{9}{|l|}{$A A D T_{\mathrm{hu}}$} \\
\hline Annual & no & from & from & from & from & from & from & below \\
\hline Average & less & 399 & 199 & 799 & 199 & 99 & 49 & 25 \\
\hline Daily Traffic & than & to & to & to & to & to & to & \\
\hline of Heavy & 4000 & 2000 & 800 & 200 & 100 & 50 & 25 & \\
\hline $\begin{array}{l}\text { Vehicles, } \\
\text { first year }\end{array}$ & & & & & & & & \\
\hline
\end{tabular}

Table 2. Subgrade categories

\begin{tabular}{cccc}
\hline $\begin{array}{c}\text { Subgrade } \\
\text { categories }\end{array}$ & $\mathbf{S 1}$ & $\mathbf{S 2}$ & $\mathbf{S 3}$ \\
\hline$E_{\mathrm{V}_{2}} \mathrm{MPa}$ & no less than 60 & no less than 120 & no less than 300 \\
\hline
\end{tabular}

categories: $\mathrm{S} 1$ and $\mathrm{S} 3$, being the ones with the lowest and highest bearing capacity respectively. Traffic categories correspond to the volume of heavy vehicles considered in the projected lane, , in the first year of the road service and are defined in Table 1 . The subgrade categories are discriminated by the deformation modulus in the second loading cycle, $E_{v_{2}}$, it is obtained from the load plate test, as it is shown in Table 2.

The 12 structural sections analysed correspond to equivalent solutions of flexible and semi-rigid pavements for the traffic categories T00, T1, T31 and T41, all supported on subgrades type S1 and S3; and are described in Table 3. In the case of semi-rigid pavements, only sections composed of asphalt mixture layers over soil-cement bases were studied because they are frequently used. Sections with gravel-cement bases (also admissible in the Spanish pavement catalogue) were discarded because of their lack of use.

Young modulus and the Poisson ratio for the characterisation of the different layers are presented in Table 4, selected from previous experience. In addition, full adhesion between the layers of the pavement was assumed in the definition of the sections.

\subsection{Load configuration of T2S3 heavy vehicle}

This heavy vehicle is the most frequent long-distance vehicle in Europe, the 2-axle tractor with a 3-axle semi-trailer, as shown in Figure 2. 
Table 3. Pavement sections studied

\begin{tabular}{|c|c|c|c|c|c|}
\hline \multirow{2}{*}{$\begin{array}{l}\text { Pavement } \\
\text { type }\end{array}$} & \multirow{2}{*}{$\begin{array}{l}\text { Traffic } \\
\text { category }\end{array}$} & \multirow[b]{2}{*}{ Subgrade } & \multicolumn{3}{|c|}{ Thickness, cm } \\
\hline & & & $\begin{array}{l}\text { Asphalt } \\
\text { mixture }\end{array}$ & $\begin{array}{c}\text { Granular } \\
\text { base }\end{array}$ & Soil-cement \\
\hline \multirow{8}{*}{ Flexible } & \multirow{2}{*}{ TOO } & S1 & * & * & - \\
\hline & & S3 & 35 & 25 & - \\
\hline & \multirow{2}{*}{$\mathrm{T} 1$} & $\mathrm{~S} 1$ & * & * & - \\
\hline & & S3 & 25 & 25 & - \\
\hline & \multirow{2}{*}{ T31 } & $\mathrm{S} 1$ & 20 & 40 & - \\
\hline & & S3 & 16 & 25 & - \\
\hline & \multirow{2}{*}{ T41 } & $\mathrm{S} 1$ & 10 & 40 & - \\
\hline & & S3 & 10 & 20 & - \\
\hline \multirow{8}{*}{ Semi-rigid } & \multirow{2}{*}{ TOO } & S1 & * & - & * \\
\hline & & S3 & 25 & - & 30 \\
\hline & \multirow{2}{*}{$\mathrm{T} 1$} & S1 & * & - & * \\
\hline & & S3 & 20 & - & 20 \\
\hline & \multirow{2}{*}{ T31 } & S1 & 15 & - & 20 \\
\hline & & S3 & 12 & - & 22 \\
\hline & \multirow{2}{*}{ T41 } & $\mathrm{S} 1$ & 8 & - & 30 \\
\hline & & S3 & 8 & - & 20 \\
\hline
\end{tabular}

Note: *there are no pavement sections for the combination of traffic and subgrade TOO-S1 and T1-S1 in the Spanish pavement catalogue.

Table 4. Young modulus and Poisson ratio of the layers considered in the analysis

\begin{tabular}{lcc}
\hline Material & $\begin{array}{c}\text { Young modulus, } \\
\text { MPa }\end{array}$ & $\begin{array}{c}\text { Poisson } \\
\text { ratio }\end{array}$ \\
\hline Asphalt mixture & 5000 & 0.35 \\
Granular base & 200 over S1 & 0.30 \\
Soil-cement & 500 over S3 & 0.25 \\
Subgrade S1 & 1500 & 0.40 \\
Subgrade S3 & 50 & 0.40 \\
\hline
\end{tabular}

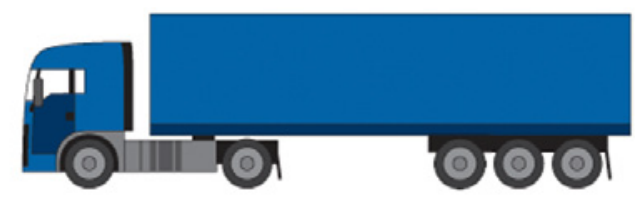

Figure 2. Heavy vehicle T2S3 configuration (modified drawing from the Federal Highway Administration, 2016)
Adriana Martínez, Magín Campos

Load Aggressiveness on Different

Pavement

Structures due to the Weight Increase of Heavy

Vehicles from

40 Tonnes to 44 Tonnes 
The vehicle consists of:

- a single axle with single tyres;

- a single axle with dual tyres;

- a tridem axle with single or twin tyres.

The impact of its axles was analysed, considering the tridem axles with single tyres as these are the most representative of the fleet, and they cause the most critical situation regarding the load distribution.

Four different maximum weights were considered - $15.5 \mathrm{t}$ (simulating the empty vehicle to account for return trips) and $40 \mathrm{t}, 42 \mathrm{t}$ and $44 \mathrm{t}$ (for the loaded scenarios). The particular characteristics of each axle and tyre are:

- wheelbase and load distribution - for a heavy vehicle with $40 \mathrm{t}$ the wheelbase and load distribution used were those recommended by a similar study developed in France (Ministère de l'écologie,... 2011), keeping axle loads below the maximum values allowed in Spain, and the weight of front axle constant. For the empty vehicle, a weight of $15.5 \mathrm{t}$ was estimated. The maximum loads per axle are regulated by Annex IX of the Spanish General Vehicle Regulations (Orden PRE/2788/2015,..., 2015), and are summarised below:

- the maximum permitted weight per drive axle - $11.5 \mathrm{t}$;

- the maximum permitted weight per tridem axle $-21 \mathrm{t}$ (wheelbase shorter than $1.30 \mathrm{~m}$ ), $24 \mathrm{t}$ (wheelbase longer $1.30 \mathrm{~m}$ and shorter than $1.40 \mathrm{~m}$ );

- contact pressures - 0.662 MPa for single axles and 0.700 MPa for tridem axles with single tyres, by the recommendation of SETRA (Service d'Etudes Techniques, 2009);

- the radius of tyre contact - keeping the contact pressure of the tyre on the pavement, the radius of the circle with an equivalent area was calculated.

\section{Results and discussion}

\subsection{Coefficient of aggressiveness - hypothesis $A$ $(\alpha=5$ - for layers of asphalt mixtures and $\alpha=12-$ for the layers of soil-cement)}

The results of aggressiveness calculated for the vehicle with different weights $(15.5 t, 40 t, 42 t$ and $44 t)$, concerning the reference axle (13 t), calculated for the selected pavement sections, are presented below. Failure parameters considered were those related with fatigue cracking: 
the horizontal tensile strain at the bottom of the asphalt layer for flexible and semi-rigid pavements; and the horizontal tensile stress at the bottom of the soil-cement layer for semi-rigid pavements additionally.

The results of the aggressiveness of heavy vehicles on the pavement sections show rising trends as the layer thicknesses of each section are reduced, Figures 3 and 4. In traffic categories T31 and T41, it is also observed that sections of flexible pavements on the best subgrade (S3) have more aggressiveness, possibly because the high bearing capacity of S3 is unable to compensate the reduction of the thickness of the pavement layers. In the case of semi-rigid pavements, the same behaviour is observed for both failure criteria (asphalt mixture and soilcement layers), except for the section of traffic T41 and the criterion of the asphalt mix layer, since here the aggressiveness increases when using subgrade $\mathrm{S} 1$.

Second, the ratio between the coefficients of aggressiveness of the empty vehicle with $15.5 \mathrm{t}$, and loaded with $42 \mathrm{t}$ and $44 \mathrm{t}$, with respect to the vehicle loaded with $40 \mathrm{t}$, were calculated and the results are collected in Tables 5-7, to make a comparison to the reference considered truck (40 t).

It was impossible to calculate the stress state of some pavement sections corresponding to the lowest traffic category (T41) because of the limitations of the calculation method. Moreover, it is recommended to avoid analytical design methods for pavement sections of this traffic

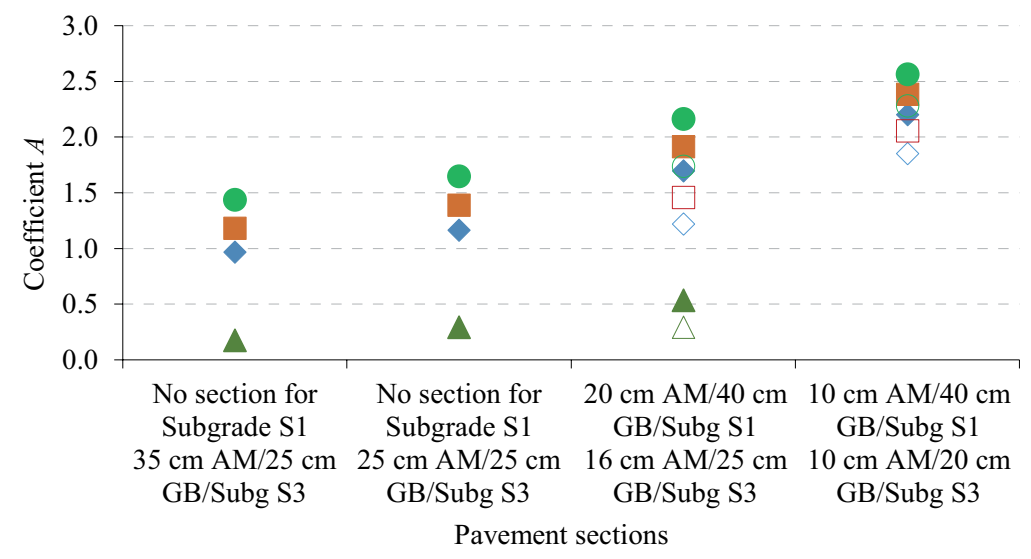

\footnotetext{
$\diamond 40$ t Subgrade S1 $\quad 40$ t Subgrade S3 $\square 42$ t Subgrade S1 $\square 42$ t Subgrade S3

44 t Subgrade S1 44 t Subgrade S3 $\triangle 15.5$ t Subgrade S1 $\Delta 15.5$ t Subgrade S3
}

Note: failure criterion in the asphalt mixture layer. Hypothesis A.

Figure 3. Aggressiveness coefficient for a heavy vehicle on flexible pavements 


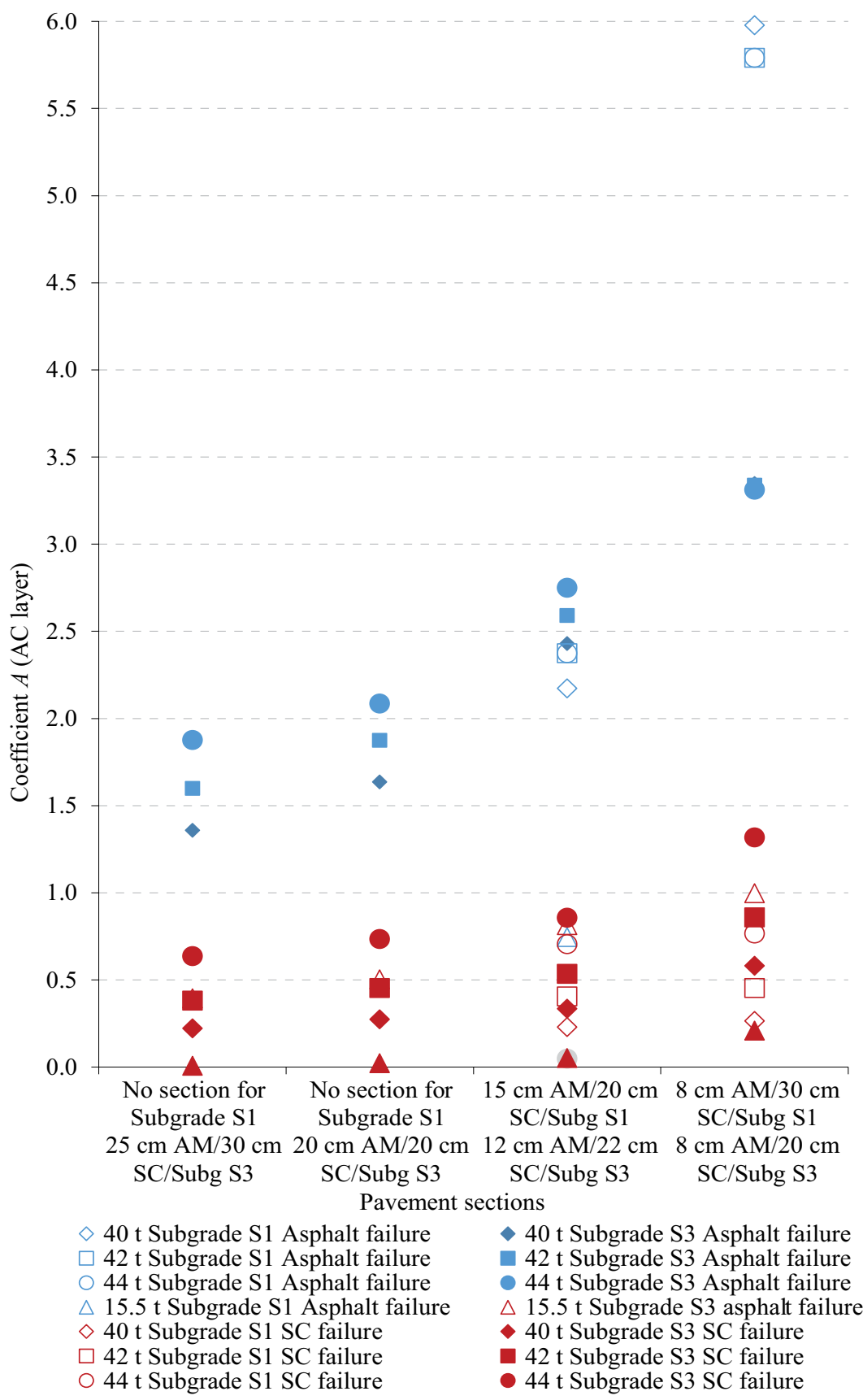

Note: failure criteria in both the asphalt mixture and the soil-cement. Hypothesis A.

Figure 4. Aggressiveness coefficient for a heavy vehicle on semi-rigid pavements 
Table 5. Aggressiveness coefficients ratio between a heavy vehicle with $15.5 \mathrm{t}$ and $40 \mathrm{t}$. Hypothesis $\mathrm{A}$

\begin{tabular}{|c|c|c|c|c|c|c|c|c|c|}
\hline \multirow{5}{*}{$\begin{array}{l}\text { Pavement, } \\
\text { traffic } \\
\text { category, } \\
\text { subgrade } \\
\text { category }\end{array}$} & \multicolumn{3}{|c|}{ Flexible pavements } & \multicolumn{6}{|c|}{ Semi-rigid pavements } \\
\hline & \multicolumn{9}{|c|}{ Strain at the bottom } \\
\hline & \multicolumn{6}{|c|}{ of the asphalt mixture layer } & \multicolumn{3}{|c|}{ of soil-cement layer } \\
\hline & \multicolumn{2}{|c|}{$A_{i} A C$} & \multirow{2}{*}{$\frac{R A C}{\frac{44}{40} t}$} & \multicolumn{2}{|c|}{$A_{i} A C$} & \multirow{2}{*}{$\frac{R A C}{\frac{44}{40} t}$} & \multicolumn{2}{|c|}{$A_{i} S C$} & \multirow{2}{*}{$\frac{R S C}{\frac{44}{40} t}$} \\
\hline & $40 t$ & $44 t$ & & $40 t$ & $44 t$ & & $40 t$ & $44 t$ & \\
\hline TOO S3 & 1. & 0 & 0.15 & 1 & $\mathrm{c}$ & 0.2 & 0.44 & 0.01 & 0.02 \\
\hline T1 S3 & 1.40 & 0.29 & 0.21 & 1.85 & 0.50 & 0.27 & 0.53 & 0.02 & 0.04 \\
\hline T31 S3 & 1.90 & 0.54 & 0.28 & 2.54 & 0.82 & 0.32 & 0.65 & 0.05 & 0.08 \\
\hline T31 S1 & 1.45 & 0.29 & 0.20 & 2.32 & 0.75 & 0.32 & 0.49 & 0.05 & 0.10 \\
\hline T41 S3 & 2.34 & - & - & 3.27 & 1.00 & 0.31 & 1.00 & 0.21 & 0.21 \\
\hline T41 S1 & 2.04 & - & - & 5.15 & - & - & 0.54 & - & - \\
\hline
\end{tabular}

Table 6. Aggressiveness coefficients ratio between a heavy vehicle with $42 \mathrm{t}$ and $40 \mathrm{t}$. Hypothesis $A$

\begin{tabular}{|c|c|c|c|c|c|c|c|c|c|}
\hline \multirow{5}{*}{$\begin{array}{l}\text { Pavement, } \\
\text { traffic } \\
\text { category, } \\
\text { subgrade } \\
\text { category }\end{array}$} & \multicolumn{3}{|c|}{ Flexible pavements } & \multicolumn{6}{|c|}{ Semi-rigid pavements } \\
\hline & \multicolumn{9}{|c|}{ Strain at the bottom } \\
\hline & \multicolumn{6}{|c|}{ of the asphalt mixture layer } & \multicolumn{3}{|c|}{ of soil-cement layer } \\
\hline & \multicolumn{2}{|c|}{$A_{i} A C$} & \multirow{2}{*}{$\frac{R A C}{\frac{44}{40} t}$} & \multicolumn{2}{|c|}{$A_{i} A C$} & \multirow{2}{*}{$\frac{R A C}{\frac{44}{40} t}$} & \multicolumn{2}{|c|}{$A_{i} S C$} & \multirow{2}{*}{$\frac{R S C}{\frac{44}{40}}$} \\
\hline & $40 t$ & $44 t$ & & $40 t$ & $44 t$ & & $40 t$ & $44 t$ & \\
\hline TOO S3 & 0.97 & 1.18 & 1.22 & 1.36 & 1.6 & 1.18 & 0.22 & 0.38 & 1.71 \\
\hline T1 S3 & 1.1 & 1.39 & 1.19 & 1.64 & 1.87 & 1.15 & 0.27 & 0.45 & 1.66 \\
\hline T31 S3 & 1.70 & 1.92 & 1.13 & 2.43 & 2.59 & 1.07 & 0.34 & 0.53 & 1.60 \\
\hline T31 S1 & 1.22 & 1.46 & 1.20 & 2.17 & 2.37 & 1.09 & 0.23 & 0.41 & 1.76 \\
\hline T41 S3 & 2.20 & 2.38 & 1.08 & 3.35 & 3.34 & 1.00 & 0.58 & 0.86 & 1.48 \\
\hline T41 S1 & 1.85 & 2.06 & 1.11 & 5.98 & 5.79 & 0.97 & 0.26 & 0.45 & 1.72 \\
\hline
\end{tabular}

category because it is known that these sections are not exhausted by fatigue phenomena but by the action of overloads (Kraemer \& Albeda, 2004).

When trucks are loaded, the load aggressiveness on flexible pavements is similar to the load aggressiveness on semi-rigid pavements when strain under the asphalt layer is analysed, but when the stress under the soil-cement layer is studied, aggressiveness is much higher
Adriana Martínez Magín Campos

Load Aggressiveness on Different

Pavement

Structures due to the Weight Increase of Heavy

Vehicles from 40 Tonnes to 44 Tonnes 
Table 7. Aggressiveness coefficients ratio between a heavy vehicle with $44 \mathrm{t}$ and $40 \mathrm{t}$. Hypothesis $A$

\begin{tabular}{|c|c|c|c|c|c|c|c|c|c|}
\hline \multirow{5}{*}{$\begin{array}{l}\text { Pavement, } \\
\text { traffic } \\
\text { category, } \\
\text { subgrade } \\
\text { category }\end{array}$} & \multicolumn{3}{|c|}{ Flexible pavements } & \multicolumn{6}{|c|}{ Semi-rigid pavements } \\
\hline & \multicolumn{9}{|c|}{ Strain at the bottom } \\
\hline & \multicolumn{6}{|c|}{ of the asphalt mixture layer } & \multicolumn{3}{|c|}{ of soil-cement layer } \\
\hline & \multicolumn{2}{|c|}{$A_{i} A C$} & \multirow{2}{*}{$\frac{R A C}{\frac{44}{40} t}$} & \multicolumn{2}{|c|}{$A_{i} A C$} & \multirow{2}{*}{$\frac{R A C}{\frac{44}{40} t}$} & \multicolumn{2}{|c|}{$A_{i} S C$} & \multirow{2}{*}{$\frac{R S C}{\frac{44}{40} t}$} \\
\hline & $40 t$ & $44 t$ & & $40 t$ & $44 t$ & & $40 t$ & $44 t$ & \\
\hline TOO S3 & 0.97 & 1.44 & 1.49 & 1.36 & 1.88 & 1.38 & 0.22 & 0.64 & 2.86 \\
\hline T1 S3 & 1.17 & 1.65 & 1.42 & 1.64 & 2.09 & 1.28 & 0.27 & 0.74 & 2.68 \\
\hline T31 S3 & 1.70 & 2.16 & 1.28 & 2.43 & 2.75 & 1.13 & 0.34 & 0.86 & 2.56 \\
\hline T31 S1 & 1.22 & 1.74 & 1.43 & 2.17 & 2.58 & 1.19 & 0.23 & 0.71 & 3.06 \\
\hline T41 S3 & 2.20 & 2.57 & 1.16 & 3.35 & 3.31 & 0.99 & 0.58 & 1.32 & 2.27 \\
\hline T41 S1 & 1.85 & 2.28 & 1.23 & 5.98 & 5.58 & 0.93 & 0.26 & 0.77 & 2.90 \\
\hline
\end{tabular}

than the previous conditions, for both cases, with $42 \mathrm{t}$ and $44 \mathrm{t}$, as reflected in Tables 6 and 7.

The most critical sections are the 0032, 3112 and 4112 for vehicles loaded with $42 \mathrm{t}$ and $44 \mathrm{t}$ (indicated in red in Tables 6 and 7), where the highest ratio corresponds to the failure in the soil-cement layer. It is interesting to highlight that there are some pavement sections at which the ratio of aggressiveness of $42 / 40$ is higher than that of $44 / 40$. In these cases, the load increase at constant pressure (assumed hypothesis) requires increasing the tire-pavement contact area, causing a decrease in the evaluated parameter $\left(\varepsilon_{i}\right)$, especially in pavements with the lowest thickness of asphalt mixture (semi-rigid pavements with T41).

\subsection{Coefficient of aggressiveness - hypothesis B} ( $\alpha=4$ - for layers of asphalt mixtures and $\alpha=8-$ for the layers of soil-cement)

Following the same procedure used in the previous stage, the results of the coefficient of aggressiveness for the vehicle with different weights $(15.5 \mathrm{t}, 40 \mathrm{t}, 42 \mathrm{t}$ and $44 \mathrm{t})$ with respect to the reference axle (13 t), calculated for the selected structural sections, are presented below, Figures 5 and 6. 


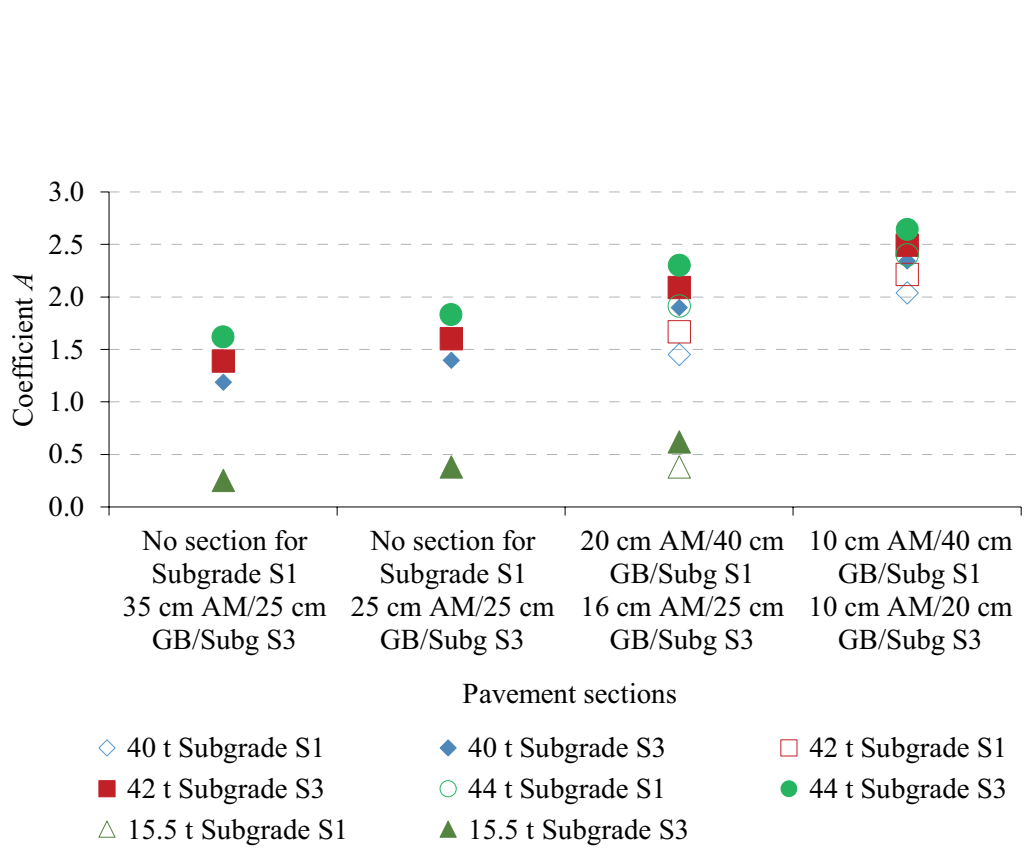

Note: Failure criterion in the asphalt mixture layer. Hypothesis B.

Figure 5. Aggressiveness coefficient for a heavy vehicle on flexible pavements.

Table 8. Aggressiveness coefficients ratio between a heavy vehicle with 15.5 t and $40 \mathrm{t}$. Hypothesis B

\begin{tabular}{|c|c|c|c|c|c|c|c|c|c|}
\hline \multirow{5}{*}{$\begin{array}{c}\text { Pavement, } \\
\text { traffic } \\
\text { category, } \\
\text { subgrade } \\
\text { category }\end{array}$} & \multicolumn{3}{|c|}{ Flexible pavements } & \multicolumn{6}{|c|}{ Semi-rigid pavements } \\
\hline & \multicolumn{9}{|c|}{ Strain at the bottom } \\
\hline & \multicolumn{6}{|c|}{ of the asphalt mixture layer } & \multicolumn{3}{|c|}{ of soil-cement layer } \\
\hline & \multicolumn{2}{|c|}{$A_{i} A C$} & \multirow{2}{*}{$\frac{R A C}{\frac{44}{40} \mathrm{t}}$} & \multicolumn{2}{|c|}{$A_{i} A C$} & \multirow{2}{*}{$\frac{R A C}{\frac{44}{40} t}$} & \multicolumn{2}{|c|}{$A_{i} S C$} & \multirow{2}{*}{$\frac{R S C}{\frac{44}{40} t}$} \\
\hline & $40 t$ & $44 t$ & & $40 t$ & $44 t$ & & $40 t$ & $44 t$ & \\
\hline TOO S3 & 1.19 & 0.25 & 0.21 & 1.59 & 0.48 & 0.30 & 0.44 & 0.04 & 0.09 \\
\hline T1 S3 & 1.40 & 0.38 & 0.27 & 1.85 & 0.59 & 0.32 & 0.53 & 0.08 & 0.15 \\
\hline T31 S3 & 1.90 & 0.62 & 0.33 & 2.54 & 0.90 & 0.36 & 0.65 & 0.14 & 0.22 \\
\hline T31 S1 & 1.45 & 0.38 & 0.26 & 2.32 & 0.82 & 0.35 & 0.49 & 0.13 & 0.27 \\
\hline T41 S3 & 2.34 & - & - & 3.27 & 1.12 & 0.34 & 1.00 & 0.35 & 0.35 \\
\hline T41 S1 & 2.04 & - & - & 5.15 & - & - & 0.54 & - & - \\
\hline
\end{tabular}



ENGINEERING

2019/14(3)

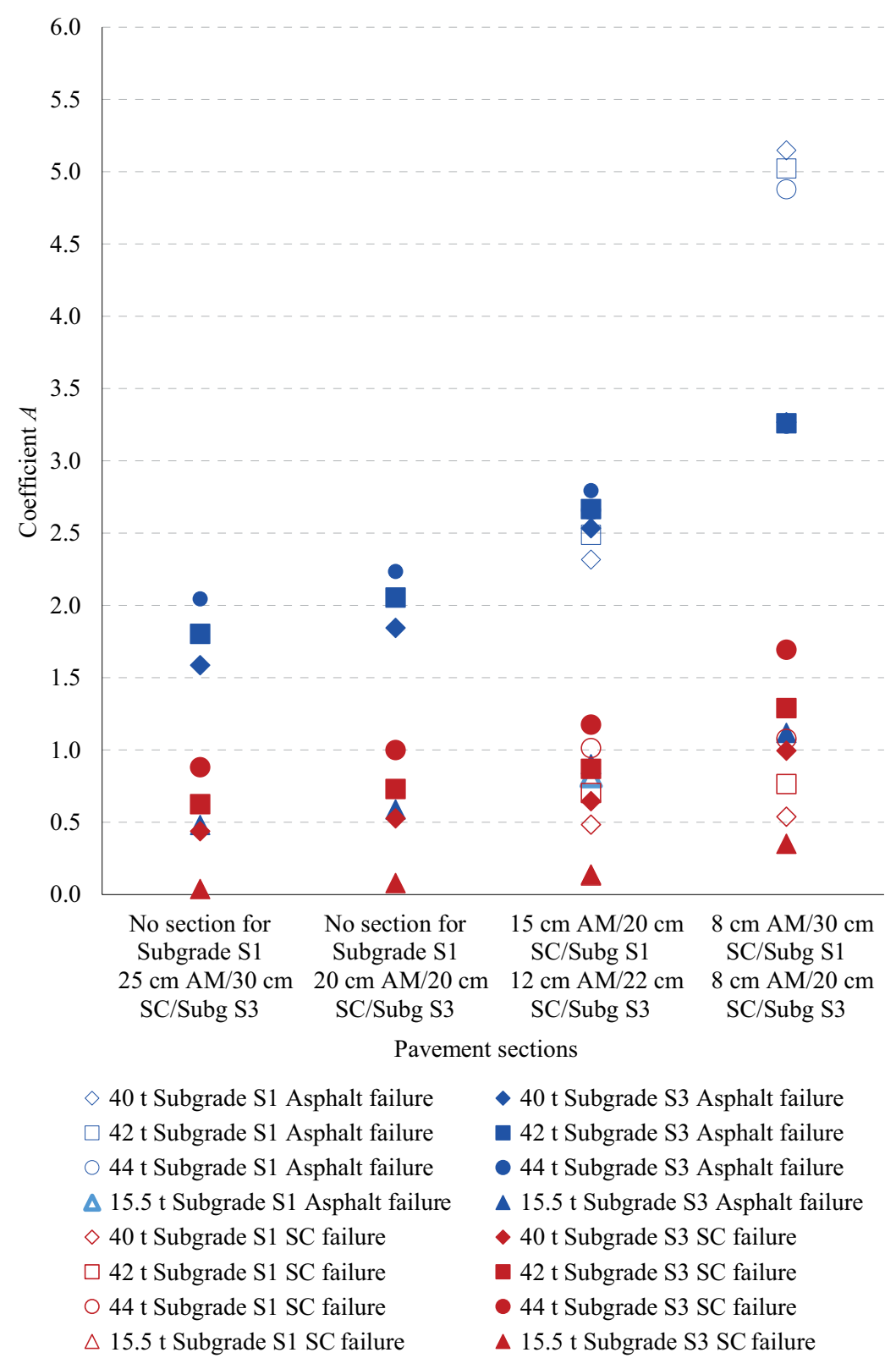

Note: failure criteria in both the asphalt mixture layer and soil-cement layer. Hypothesis B.

Figure 6. Aggressiveness coefficient for a heavy vehicle on semi-rigid pavements 
Analogous to the analysis under the hypothesis $\mathrm{A}$, the ratio between the coefficients of aggressiveness for empty vehicles with $15.5 \mathrm{t}$, loaded with $42 \mathrm{t}$ and $44 \mathrm{t}$ concerning the vehicle loaded with $40 \mathrm{t}$, was calculated for hypothesis B, Tables 8-10. Average, maximum and minimum values of all ratios for both hypotheses are collected in Figure 7 to have a global view of the results.

The coefficients for the empty vehicle with $15.5 \mathrm{t}$ are shown in Table 8. As happened in the analysis of hypothesis A, it was impossible to

Table 9. Aggressiveness coefficients ratio between a heavy vehicle with $42 \mathrm{t}$ and $40 \mathrm{t}$. Hypothesis $\mathrm{B}$

\begin{tabular}{|c|c|c|c|c|c|c|c|c|c|}
\hline \multirow{5}{*}{$\begin{array}{l}\text { Pavement, } \\
\text { traffic } \\
\text { category, } \\
\text { subgrade } \\
\text { category }\end{array}$} & \multicolumn{3}{|c|}{ Flexible pavements } & \multicolumn{6}{|c|}{ Semi-rigid pavements } \\
\hline & \multicolumn{9}{|c|}{ Strain at the bottom } \\
\hline & \multicolumn{6}{|c|}{ of the asphalt mixture layer } & \multicolumn{3}{|c|}{ of soil-cement layer } \\
\hline & \multicolumn{2}{|c|}{$A_{i} A C$} & \multirow{2}{*}{$\frac{R A C}{\frac{44}{40} t}$} & \multicolumn{2}{|c|}{$A_{i} A C$} & \multirow{2}{*}{$\frac{R A C}{\frac{44}{40} t}$} & \multicolumn{2}{|c|}{$A_{i} S C$} & \multirow{2}{*}{$\frac{R S C}{\frac{44}{40}}$} \\
\hline & $40 t$ & $44 t$ & & $40 t$ & $44 t$ & & $40 t$ & $44 t$ & \\
\hline TOO S3 & 1.19 & 1.39 & 1.17 & 1.59 & 1.81 & 1.14 & 0.44 & 0.63 & 1.42 \\
\hline T1 S3 & 1.40 & 1.60 & 1.15 & 1.85 & 2.05 & 1.11 & 0.53 & 0.73 & 1.38 \\
\hline T31 S3 & 1.90 & 2.09 & 1.10 & 2.54 & 2.67 & 1.05 & 0.65 & 0.87 & 1.35 \\
\hline T31 S1 & 1.45 & 1.67 & 1.15 & 2.32 & 2.49 & 1.07 & 0.49 & 0.70 & 1.45 \\
\hline T41 S3 & 2.34 & 2.49 & 1.06 & 3.27 & 3.26 & 1.00 & 1.00 & 1.29 & 1.30 \\
\hline T41 S1 & 2.04 & 2.22 & 1.09 & 5.15 & 5.02 & 0.98 & 0.54 & 0.76 & 1.42 \\
\hline
\end{tabular}

Table 10. Aggressiveness coefficients ratio between a heavy vehicle with $44 \mathrm{t}$ and $40 \mathrm{t}$. Hypothesis B

\begin{tabular}{|c|c|c|c|c|c|c|c|c|c|}
\hline \multirow{5}{*}{$\begin{array}{l}\text { Pavement, } \\
\text { traffic } \\
\text { category, } \\
\text { subgrade } \\
\text { category }\end{array}$} & \multicolumn{3}{|c|}{ Flexible pavements } & \multicolumn{6}{|c|}{ Semi-rigid pavements } \\
\hline & \multicolumn{9}{|c|}{ Strain at the bottom } \\
\hline & \multicolumn{6}{|c|}{ of the asphalt mixture layer } & \multicolumn{3}{|c|}{ of soil-cement layer } \\
\hline & \multicolumn{2}{|c|}{$A_{i} A C$} & \multirow{2}{*}{$\frac{R A C}{\frac{44}{40} \mathrm{t}}$} & \multicolumn{2}{|c|}{$A_{i} A C$} & \multirow{2}{*}{$\frac{R A C}{\frac{44}{40} t}$} & \multicolumn{2}{|c|}{$A_{i} S C$} & \multirow{2}{*}{$\frac{R S C}{\frac{44}{40}}$} \\
\hline & $40 t$ & $44 t$ & & $40 t$ & $44 t$ & & $40 t$ & $44 t$ & \\
\hline TOO S3 & 1.19 & 1.62 & 1.36 & 1.59 & 2.05 & 1.29 & 0.44 & 0.88 & 2.00 \\
\hline T1 S3 & 1.40 & 1.83 & 1.31 & 1.85 & 2.23 & 1.21 & 0.53 & 1.00 & 1.89 \\
\hline T31 S3 & 1.90 & 2.30 & 1.21 & 2.54 & 2.80 & 1.10 & 0.65 & 1.18 & 1.82 \\
\hline T31 S1 & 1.45 & 1.91 & 1.32 & 2.32 & 2.66 & 1.15 & 0.49 & 1.01 & 2.09 \\
\hline T41 S3 & 2.34 & 2.64 & 1.13 & 3.27 & 3.24 & 0.99 & 1.00 & 1.69 & 1.70 \\
\hline T41 S1 & 2.04 & 2.40 & 1.18 & 5.15 & 4.88 & 0.95 & 0.54 & 1.08 & 2.00 \\
\hline
\end{tabular}

Adriana Martínez, Magín Campos

Load Aggressiveness on Different

Pavement

Structures due to the Weight Increase of Heavy

Vehicles from 40 Tonnes to 44 Tonnes 


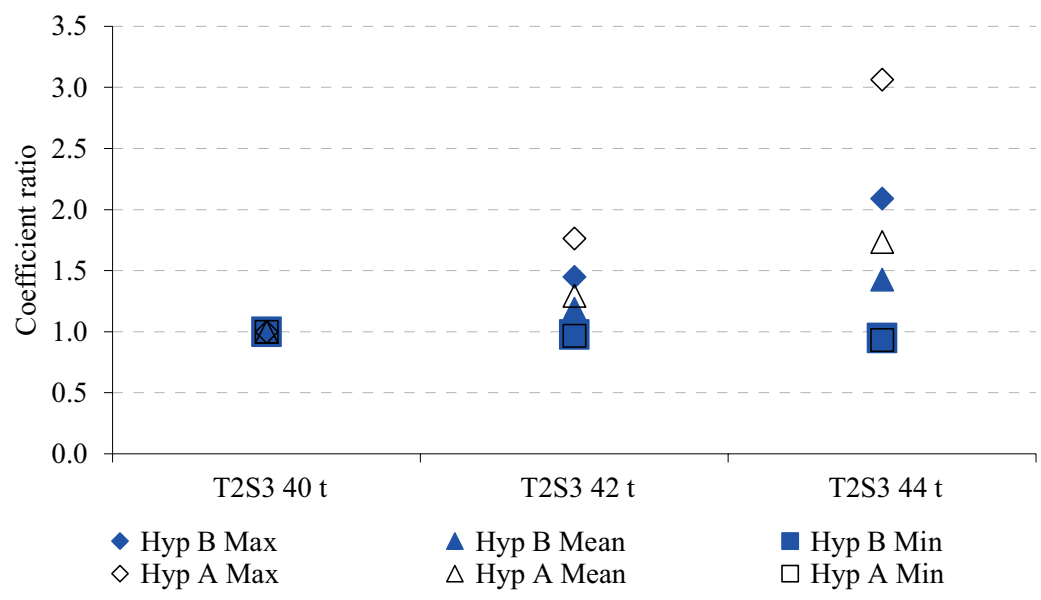

Figure 7. Maximum, minimum and mean values of the coefficient ratio

calculate the stress state of some structures corresponding to the lowest traffic category (T41) by the limitations of the method.

Following the same trend as the results obtained under the hypothesis $A$, the ratios calculated for the loaded vehicles show that the three most critical sections of semi-rigid pavements for vehicles with $42 \mathrm{t}$ and $44 \mathrm{t}$, are those of sections 0032,3112 and 4112, indicated in Tables 8 and 9 in red.

\subsection{Comparison of the results with both hypotheses}

Under hypothesis A, going from $42 \mathrm{t}$ to $44 \mathrm{t}$ means an increase of aggressiveness between $7 \%$ and $22 \%$ (depending on the section considered) in the case of flexible pavements. For semi-rigid pavements, the increase varies from $0 \%$ to $17 \%$ when the criterion of the asphalt layer is considered and from 53\% and 73\% when the stress under the soil-cement layer is analysed.

Under hypothesis $\mathrm{B}$, the increase of aggressiveness when changing from 42 t to $44 \mathrm{t}$ in flexible pavements ranges between $6 \%$ and $16 \%$; and there is a similar variation for semi-rigid pavements, from $0 \%$ to $13 \%$, when asphalt layers are analysed; and between $30 \%$ and $40 \%$ when soilcement layers are evaluated. The notable difference among the results obtained with both hypotheses shows the sensitivity of the parameter analysed.

When the maximum coefficients obtained with respect to the truck loaded with $40 \mathrm{t}$ are compared, it is clear that the aggressiveness of a vehicle loaded with $44 \mathrm{t}$ is no more than three times the value of the 


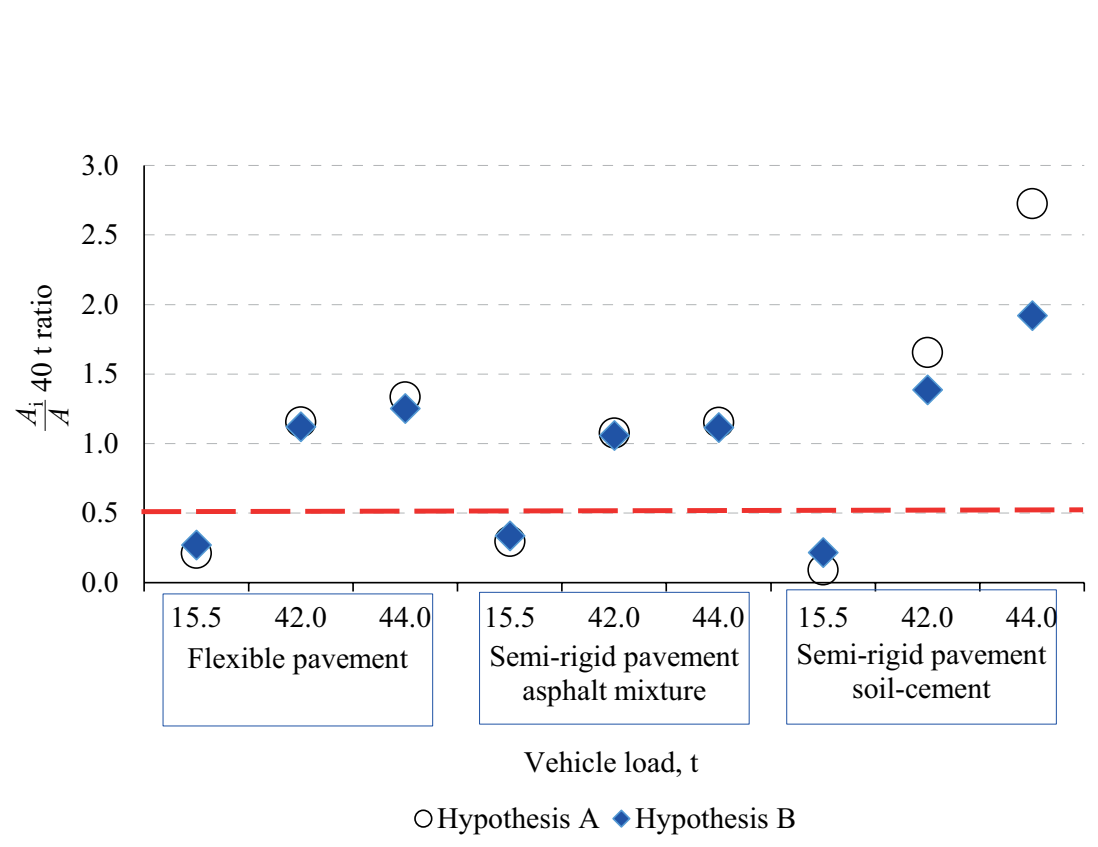

Note: hypotheses A and B.

Figure 8. Mean values of the ratios between the coefficients of aggressiveness of each load and $40 t$

aggressiveness of a vehicle loaded with $40 \mathrm{t}$ with the hypothesis $\mathrm{A}$ (ratio 3.06), and no more than twice the value with the hypothesis B (ratio 2.09).

To conclude this section, the mean values of the ratios presented in the above tables for each vehicle weight analysed over each pavement type and under the two hypotheses, are collected in Figure 8. From the comparison of these results, it is clear that the soil-cement layer in semirigid pavements is the critical factor.

\section{Conclusions}

The objective of this study was to evaluate the aggressiveness caused by a heavy vehicle type T2S3 (two tractor axles and 3-axle semitrailer) when its maximum weight increases from $40 \mathrm{t}$ (maximum value authorised in Spain) to $42 \mathrm{t}$ and $44 \mathrm{t}$, considering that other European countries admit these two limits. Different sectors of society are currently discussing the possibility of increasing Spanish restriction.

1. The calculations of the stresses and strains caused by this heavy vehicle on the pavement were performed, taking into account two 
different hypotheses (A and B). Hypothesis A is used in France, where there is extensive experience in this type of studies and where the circulation of vehicles with $44 \mathrm{t}$ is allowed. Hypothesis $B$ is usually recommended in Spanish literature. Both hypotheses differ from each other by the value of the factor-alpha (coefficient associated with the slope of the fatigue law of the materials) used in the calculation of aggressiveness.

2. The results obtained show that there are no significant differences under both hypotheses in the case of flexible pavements and the case of semi-rigid pavements when the failure criterion used is that of the asphalt mixture. However, the differences are significant when analysing the case of semi-rigid pavements, and the failure criterion is applied to the soil-cement layer. For these reasons, the authors consider that hypothesis A, proposed by the French Service d'Etudes Techniques des Routes et Autoroutes Incidence des PL sur les coûts de construction des chaussées neuves, with an alpha coefficient of 5 for asphalt mixtures and 12 for soilcement must be used in the case of semi-rigid pavements to adopt a much more conservative position and ensure the good behaviour of the pavements.

3. From the study carried out, the results reveal that when the load of the heavy vehicle goes from $40 \mathrm{t}$ to $44 \mathrm{t}$, the aggressiveness increases no more than 1.49 in flexible pavements and 3.06 in semi-rigid pavements.

4. The usefulness of the study conducted resides in potentially estimating the impact that a change in the legislation on the maximum permitted load in the vehicles studied will cause. On the one hand, the detrimental effect of the increased load on pavements must be evaluated, taking into account the proportion of heavy vehicles T2S3 type present in the vehicle fleet and the potential transfer of weight. On the other, advantages such as reducing the specific fuel consumption and greenhouse gas emissions, reduction of the vehicle density in circulation (improvement of the level of service) and optimisation of freight transport, must also be considered.

\section{REFERENCES}

Alianza por la competitividad de la industria Española (2013). INECO. Estudio sobre la conveniencia y viabilidad de aumentar la MMA de los vehículos pesados a 44 t. July 2013. (in Spanish) 
Burmister, D. M., Palmer, L. A., Barber, E. S., \& Middlebrooks, T. A. (1944). The theory of stress and displacements in layered systems and applications to the design of airport runways. In Highway Research Board Proceedings (Vol. 23).

Conselleria d'Infraestructures i Transport (2009). Normas de secciones de firme de la Comunidad Valenciana. (in Spanish)

Corté, J. F., \& Goux, M. T. (1996). Design of pavement structures: the French technical guide. Transportation Research Record, 1539(1), 116-124. https://doi.org/10.1177\%2F0361198196153900116

Council Directive 96/53/EC of 25 July 1996 laying down for certain road vehicles circulating within the Community the maximum authorized dimensions in national and international traffic and the maximum authorized weights in international traffic.

Dauzats, M., Kobisch, R., Leroux, C., Odeon, H., Maribas, J., \& Delorme, J. (2003). Construction Des Chaussees Neuves Sur Le Reseau Routier National-Specification Des Variantes-Guide Technique. (in French)

Díaz, R., Echaveguren, T., \& Vargas-Tejeda, S. (2012). Camiones de alto tonelaje y su impacto en ciclo de vida de pavimentos asfálticos. Revista de la Construcción, 11(1), 101-118. https://doi.org/10.4067/S0718-915X2012000100010 (in Spanish)

Dirección General de Tráfico, Ministerio del Interior, Gobierno de España (Spanish General Traffic Directorate) (2013). Reglamentación sobre vehículos pesados, prioritarios, especiales, de transporte de personas y mercancías y tramitación administrativa. Issue 2013. (in Spanish)

European Commission Directorate-General for Communication (2014). The EU explained: Transport. Citizens information. Belgium. Manuscript updated in November 2014. ISBN 978-92-79-42777-0.

Federal Highway Administration (2016). FHWA Vehicle Classification. Online Manuals. USA.

Gobierno de España (Spanish Ministry of Public Works). (January, 2016). Observatorio del Transporte de Mercancías por Carretera. Oferta y Demanda. Ministerio de Fomento. (in Spanish)

Hedberg, S. (2008). Monitoring of weights and dimensions of loading units in intermodal transport. The modular concept in practice: Experiences made in Sweden, Swedish Road Administration, presentation at the UNECE WP 24, 2008.

Highway Research Board (1961). The AASHO Road Test: Report 1, History and Description of the Project. Special Report 61A. National Academy of Sciences. Washington, D.C., USA, 1961.

International Transport Forum (2016). Road Transport-Weights and Dimensions. Permissible maximum weights of lorries in Europe (in tonnes). Retrieved from http://www.internationaltransportforum.org/

Kerzreho, J. P., Hornych, P., Chabot, A., Trichet, L., Gouy, T., Coirier, G., \& Deloffre, L. (2012, September). Evaluation of the aggressiveness of different multi-axle loads using APT tests. In 4th International Conference on Accelerated Pavement Testing (pp. 505).
Load Aggressiveness on Different

Pavement

Structures due

to the Weight

Increase of Heavy

Vehicles from

40 Tonnes to

44 Tonnes 
Kraemer, C. \& Albeda, R. (2004). Evaluación técnico-económica de las secciones del firme de la norma 6.1-IC. VI Congreso Nacional de Firmes. León, Spain, 2004. (in Spanish)

Kraemer, C., Pardillo, J. M., Rocci, S., Romana, M., Sánchez, V. \& del Val, M. A. (2004). Ingeniería de Carreteras. Vol. II. Editorial McGraw Hill, 2004. (in Spanish)

Leduc, G. (2009). Longer and Heavier Vehicles. An overview of technical aspects. JRC Scientific and Technical Reports. European Commission. Joint Research Centre. Institute for Prospective Technological Studies. European Communities, 2009.

Leonardi, J., \& Baumgartner, M. (2004, June). CO2 Reduction and Efficiency in Road Freight Transport-Measures, Baseline and Potential. In Presentation for the 23rd meeting of the International Energy Workshop (pp. 22-24).

Ministère de l'écologie, de l'énergie, du développement durable et de la mer (French Ministry of Ecology) (January, 2011). Conseil général de l'environnement et du développement durable. Rapport au Parlement sur les enjeux et les impacts relatifs à la généralisation de l'autorisation de circulation des poids lourds de 44 tonnes. (in French)

Norma 6.1-IC "Secciones de firme", aprobada por la Orden FOM 3460/2003. Gobierno de España (Spanish Ministry of Public Works). November, 2003. (in Spanish)

Orden PRE/2788/2015, de 18 de diciembre, por la que se modifica el anexo IX del Reglamento General de Vehículos, aprobado por Real Decreto 2822/1998, December 2015. (in Spanish)

Service d'Etudes Techniques des Routes et Autoroutes - Laboratoire central des ponts et chaussées (SETRA-LCPC) (1994). Conception et dimensionnement des structures de chaussée. Guide Technique. Ministère de l'équipement des Transport et du Tourisme. Paris, France, 1994. (in French)

Service d'Etudes Techniques des Routes et Autoroutes (SETRA) (2009). Incidence des PL sur les coûts de construction des chaussées neuves. Ministère de l'écologie, de l'énergie, du développement durable et de la mer (French Ministry of Ecology), April 2009. (in French)

Steer, J., Dionori, F., Casullo, L., Vollath, C., Frisoni, R., Carippo, F., \& Ranghetti, D. (2013). A Review of Megatrucks - Major Issues and Case Studies. Directorate general for internal policies, Policy department B: Structural and cohesion policies, Transport and tourism. 